\title{
Potential of Shallow Groundwater for Household Level Irrigation Practices in Tahtay Koraro Woreda, Tigray, Northern Ethiopia
}

\section{Ermias Hagos*, Amare Girmay and Tesfamichael Gebreyohannes}

School of Earth Sciences, College of Natural and Computational Sciences, Mekelle University, Mekelle, Ethiopia (*ermiash2010@gmail.com).

\begin{abstract}
This paper deals with the results of a pilot study conducted to estimate the shaloow groundwater resource potential and irrigation capacity at household-level in Tahtay Koraro Woreda, northwestern zone of Tigray, Ethiopia. The potential evapotranspiration and actual evapotranspiration of the study area are estimated to be $1484 \mathrm{~mm} / \mathrm{year}$ and $814 \mathrm{~mm} / \mathrm{year}$ respectively. The runoff is approximately calculated to be $280 \mathrm{~mm} / \mathrm{year}$ and the annual groundwater recharge is estimated to be $29 \mathrm{~mm} / \mathrm{year}$. The total annual groundwater abstraction for human, livestock and irrigation is estimated to be $25 \mathrm{~mm} /$ year. It should be noted that the groundwater recharge rate is expected to remain constant while the total annual groundwater discharge is expected to increase from year to year. This relation when projected over a long period may result in negative groundwater budget which can result in depletion of groundwater (lowering of groundwater levels), reduced baseflow to streams and deterioration of water quality. The computed values for hydraulic conductivity of the aquifers range from $1.63 \mathrm{~m} /$ day to $7.27 \mathrm{~m} /$ day with average value of $4.9 \mathrm{~m} /$ day and the transmissivity from 48.9 $\mathrm{m}^{2} /$ day to $218.1 \mathrm{~m}^{2} /$ day with average value of $147.14 \mathrm{~m}^{2} /$ day. The aquifers in the highly weathered basalt and highly weathered siltstone - sandstone intercalation have transmissivity values ranging from $99 \mathrm{~m}^{2} /$ day to $218.1 \mathrm{~m}^{2} /$ day with an average value of $157 \mathrm{~m}^{2} /$ day and are grouped into the moderate potentiality aquifers category. The aquifers in the slightly weathered and fractured metavolcanics grouped under low potentiality based on the lower transmissivity values $\left(<50 \mathrm{~m}^{2} /\right.$ day). The study area has low to moderate groundwater potentiality, hence, large scale groundwater pumping is not possible. Therefore, the current activity of using hand dug wells for household -level irrigation is the best way of using groundwater for irrigation and other uses as well. Increasing the depth of the existing hand dug wells that are constructed in highly weathered basalt and highly weathered siltstone sandstone intercalation can also enhance the yield of the hand dug wells. It is recommended to use water saving irrigation technologies rather than increasing the number of wells. This will also help in increasing the irrigation area. Groundwater recharge enhancement structures such as trenches, percolation ponds and check dams be constructed in scientifically selected localities to further enhance the groundwater potential.
\end{abstract}

Keywords: Shallow groundwater, Water budget, Aquifer properties, Northern Ethiopia.

\section{INTRODUCTION}

Water is a very important abiotic component of the environment and supports life on earth. Out of the available freshwater, $22.9 \%$ is in aquifers (groundwater), $0.5 \%$ in lakes, rivers, soil, and in the atmosphere, and the remaining in ice caps and glaciers (Vovich, 1979). The objective of managing water resources is beyond reduction of hunger and poverty through its effects on increasing agricultural production (Fletcher et al., 1995). Ethiopia also recognized 
water as the most important factor for the transformation of the agrarian system (FAO, 1994). Meeting the needs of people and reducing extreme poverty and hunger is one of the main targets of the sustainable development goals (SDGs) by ensuring peoples`access to water for growing food and ensuring income. In order to meet these goals, a potential shift from nonproductive to productive water use is very essential. Hence, the study area in Tahtay Koraro Woreda is selected as one of the pilot areas to make a paradigm shift in the agricultural sector by implementing household-based irrigation practices. According to Tigray Bureau of Plan and Finance report (BoPF, 2018), about 83,000 ha of land of the region (39.3\% of the irrigation potential) has already been irrigated and the coverage is largely contributed by the small scale water harvesting schemes. This report also revealed that the irrigation coverage in the region is progressively increased from 18,200 ha in 2013 to around 38,180 ha in 2014; around 40,845 in 2016; and around 83,000 ha in 2017. The number of farmers engaged in irrigation, has also grown from 159,295 in 2012 to 378,654 in 2017 , where small scale irrigation schemes contributes more than 90\% (BoPF, 2018). Thus, construction of small scale water harvesting schemes (including hand dug wells) has become one of the core activities both by the individuals and the government. The issue of groundwater however demands due attention.

The study area Belles watershed in Tahtay Koraro Woreda is one of the selected intervention areas in NW Tigray based on the assumption that it has the potential for farmerbased irrigation. Accordingly, substantial amount of total cultivable land has been irrigated using different water harvesting schemes for the last few years.

Regarding hydrogeological investigations, Beyth and Shachnai (1972) have conducted a hydrogeological investigation in the vicinity of the study area, which might be the first in the northern part of the country. According to this study; the rain water that percolates into the aquifer of the volcanic sequences shortly emerges as contact springs at the contact with the underlying impermeable lateritic horizons. Later, Tahal-MCE (2007) has undertaken a comprehensive hydrogeological feasibility study for the groundwater development of Shire Endassilasie town. This study has provided useful information about the hydrogeological setting of the area, the main groundwater -bearing horizons and its recharge areas. The hydrological findings in Mailiham as one of the well fields for Endassilasie town domestic water supply, shows over $75 \%$ of groundwater was found from the upper (volcanic) aquifer (Tahal-MCE, 2007). Accordingly, deep well drilling is not necessarily a guarantee for a high discharge of boreholes in the area because the aquifers in 
the volcanic sequence have local extent and limited thickness. The existing drilled boreholes and shallow wells give very small amount of yield for abstraction to the town.

The hand dug wells, which are serving as source of water for the irrigation in the area, were not developed based on hydrogeological findings. Because of this, data such as aquifer dimensions, aquifer properties, amount of groundwater recharge, wells safe yield and extents of well interference are not yet documented. In the study area, it is common to observe lowering of the static water levels of the wells and decrease of wells' discharge/ drying through time. Hence, the command area each well was supposed to irrigate is mostly not achieved and in some wells the irrigated crops became dry before production. There are also cases where irrigation beneficiaries' conflict because of well interference especially in the late months of the dry season. In general, the reasons for the success of some of the wells and failure of others not yet studied. Thus, this paper tries to assess the potential of shallow groundwater for household -level irrigation from hand dug wells in the study area.

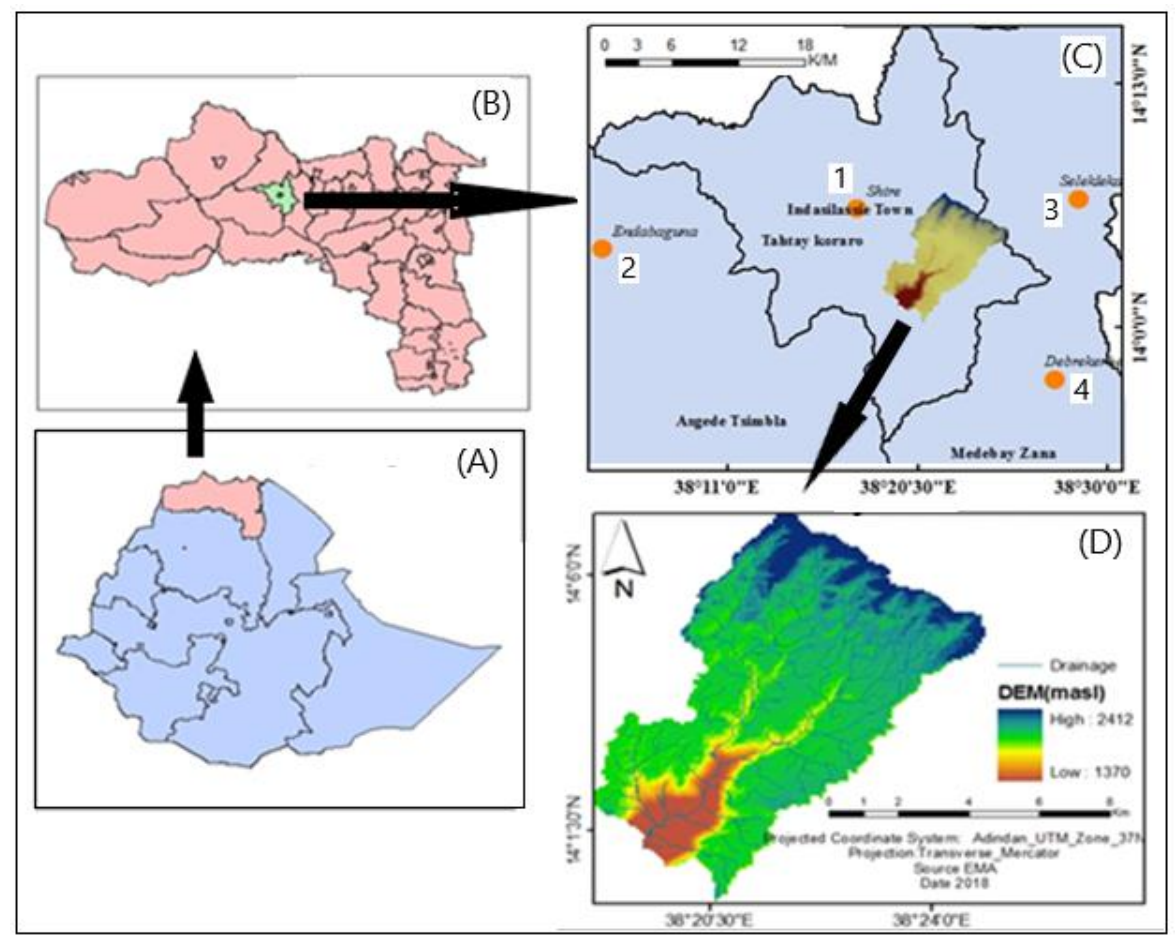

Figure 1. A). Location map, A) Ethiopia with Regions; B) Tigray with Woredas; C) Tahtay Koraro Woreda with Meteorological Stations, 1. Shire, 2. Endabaguna, 3. Selekleka 4. Debrekerbe; and D) Belles Watershed, the study area.

\section{THE STUDY AREA}

The study area covers an area of $34.4 \mathrm{Km}^{2}$, and is in Tahtay Koraro Woreda, northwestern Tigray, northern Ethiopia (Fig 1). It is about $350 \mathrm{~km}$ from Mekelle and is geographically located between $14^{\circ} 2{ }^{\prime} 30^{\prime}$ 'to $14^{\circ} 6^{\prime} 30^{\prime}$ ' longitude and $38^{\circ} 22^{\prime} 0^{\prime \prime}$ ' to $38^{\circ} 25^{\prime} 0^{\prime \prime}$ latitude. The area 
is accessible by asphalt road about $40 \mathrm{~km}$ from Axum on the way to Shire. The study area belongs to Weyna Dega (cool sub-humid) agro-climatic zone (Alemneh, 2003). The average annual rainfall of the study area is $1123 \mathrm{~mm}$ with a unimodal rainfall pattern. The mean monthly temperature ranges between $19.4^{\circ} \mathrm{C}$ and $23.8^{\circ} \mathrm{C}$, in which the hottest month is May with an average of $23.8^{\circ} \mathrm{C}$ while the coldest month is December with mean temperature of $19.4^{\circ} \mathrm{C}$. There are intermittent springs at the mouth of the gorge indicating a discharge area. Man-made soil and water conservation structures like stone bunds, trenches and gabions are observed in the area which can have an influence on the natural drainage characteristics of the area.

The distribution of different land use/land cover in the study area is as shown in table 1 and figure 2A. Three soil textural classes were recognized in the study area: clay loam, clay, and silt clay soils that covers $31.24 \%, 42.14 \%$ and $26.62 \%$ of the total area respectively (Fig 2B) (Tigray Agricultural Research Institute (TARI), 2012, unpublished data). As observed from gully outcrops and dug pits the soil is thick in the flat and gentle areas.

Table 1. Areal extents of different Land use /land cover.

\begin{tabular}{|lll|}
\hline Land use Type & Areal coverage $\left.\mathbf{( k m}^{\mathbf{2}}\right)$ & Percentage (\%) \\
\hline Vegetation land & 12.57 & 36.53 \\
\hline Settlement & 4.49 & 13.05 \\
\hline Agricultural land & 10.397 & 30.21 \\
\hline Bare land & 6.953 & 20.21 \\
\hline Total & 34.41 & 100 \\
\hline
\end{tabular}

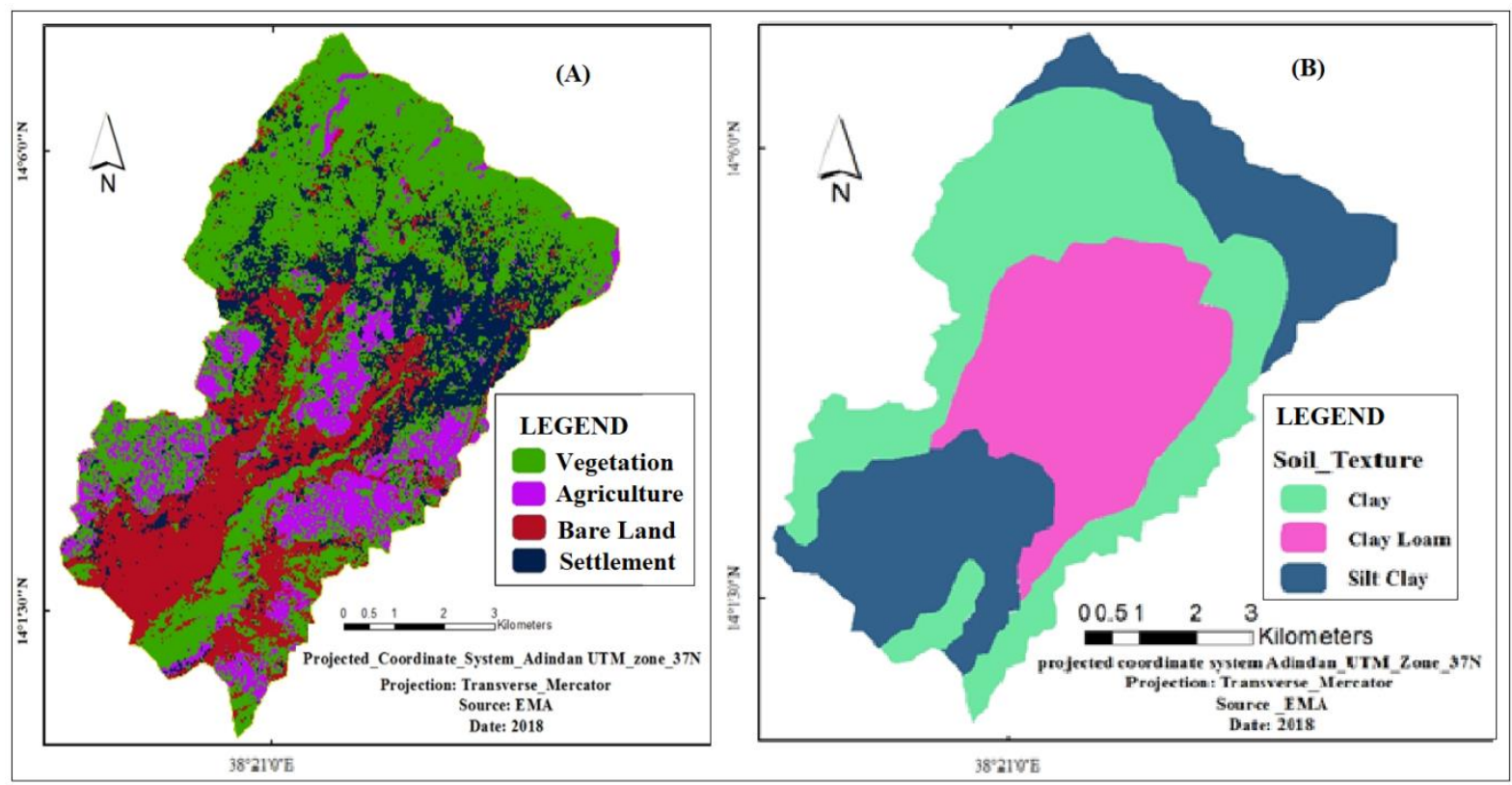

Figure 2. A) Land use land cover map; and B) Soil texture map of the study area. 


\section{METHODOLOGY}

During this study primary data was collected from the field and secondary hydrometeorological data is obtained from the meteorological stations such as Shire, Selekleka, Endabaguna and Debrekerbe stations (Fig 1) which are in the vicinity of the study area. The data was collected from the Ethiopian meteorological agency, Mekelle branch. The average areal depth of precipitation for the area was estimated by using the Isohyetal method as it accounts for the orographic effect. Other meteorological data such as temperature, relative humidity, sunshine hour and wind speed were also considered for the estimation of PET.

\subsection{Evapotranspiration}

\subsubsection{Potential Evapotranspiration (PET) Estimation}

Although various methods are used to estimate potential evapotranspiration (Penman, 1948; Jensen et al., 1990; Makink, 1957; Priestley and Taylor, 1972; Thornthwaite, 1948; and Hargreaves and Samani, 1982) in the present study the Thornthwaite (1948) method is used.

\subsubsection{Thornthwaite (1948) Method}

The Thornthwaite method uses air temperature as an index of the energy available for evapotranspiration, assuming that air temperature is correlated with the integrated effect of net radiation and other controls of evapotranspiration and the available energy is shared in fixed proportion between heating the atmosphere and generating evapotranspiration. The equation for calculating PET on monthly basis is given below (Thornthwaite, 1948).

$$
P E T=16 N m\left[\frac{10 T_{a}}{I}\right]^{a}
$$

Where,

PET $=$ Potential evapotranspiration in $\mathrm{mm} / \mathrm{month}$

$\mathbf{T a}=$ average monthly temperature $\left({ }^{0} \mathrm{C}\right)$.

$\mathbf{N}_{\mathbf{m}}=$ is monthly adjustment factor depending on latitude and season (monthly adjustment factor related to hours of day light (N/12) for the appropriate latitude).

$\mathbf{I}=$ annual heat index obtained by adding monthly heat index $\left(I_{m}\right)$ of 12 months.

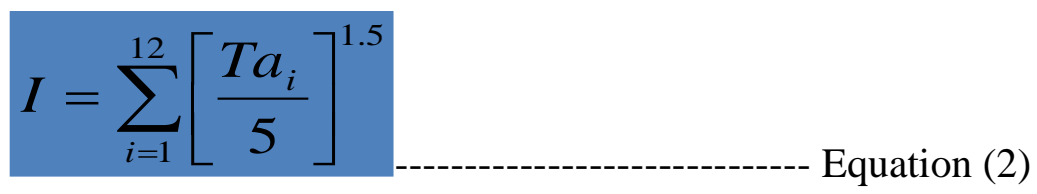

$a=0.49+0.0179 I-0.0000771 I^{2}+0.000000675 I^{3}=2.203$

\subsubsection{Actual evapotranspiration (AET)}

Actual evapotranspiration is the amount of evapotranspiration that occurs under the field conditions (Fetter, 1988). In the present study, three methods Turc method, Crowe and 
Thornthwaite method, and Thornthwaite and Mather soil water balance method are employed to calculate the AET.

\subsubsection{Turc (1961) Method}

Based on the rainfall and temperature data Turc (1961) has developed equation for computing AET. Turc has also showed that the formula can be applied in humid or arid climates either hot or cold (Shaw, 1988).

$$
A E T=\frac{P}{\left[(1.9+P / J)^{2}\right]^{0.5}}
$$

Where,

$\mathrm{T}=$ annual average temperature $\left({ }^{\circ} \mathrm{C}\right)$

$\mathrm{P}=$ the mean annual rate of precipitation in $\mathrm{mm}$

AET $=$ Annual actual evapotranspiration .

$$
\mathrm{J}=300+25 \mathrm{~T}+25 \mathrm{~T}^{3}
$$

\subsubsection{Crowe (1971) Method}

In this method temperature is considered a significant parameter to estimate AET.

$$
\mathrm{AET}=\left(\frac{\mathrm{T}-10}{9}\right)
$$

Where, $\mathrm{T}$ is temperature in ${ }^{\mathrm{o}} \mathrm{k}$.

\subsubsection{Soil Water Balance (Thornthwaite and Mather, 1957) Method}

Soil Water Balance method proposed by Thornthwaite and Matter (1957) considers the soil texture and land use pattern in addition to the meteorological parameters. This method calculates actual evapotranspiration using precipitation and soil moisture deficit values. For this study, the available water capacity (AWC) of the soil texture for different land uses is modified from the table developed by Thornthwaite and Mather (1957).

Accordingly, if the soil texture is silty clay, and the vegetation is of deep rooted crops such as alfalfa, pasture grasses, shrubs etc., available water capacity is estimated to be about $250 \mathrm{~mm}$. If soil texture is clayey and the vegetation is shallow rooted crop such as spinach, peas, beans, beets, carrot etc., the available water capacity is about $75 \mathrm{~mm}$. If soil texture is clayey loam and the vegetation is moderately-deep rooted crops such as grasses, shrubs, sorghum, maize etc., the available water capacity is about $200 \mathrm{~mm}$.

Based on the soil water balance approach, the AET of a given month equals the potential rate when the precipitation exceeds potential evapotranspiration. This is because the rain water is considered to be easily available to the plant even if the soil moisture of the whole root zone is not raised to the available water capacity. Based on this assumption and the computations in the tables below (Tables 9, 10 and 11), the AET for each soil type with 
its respective land use in the study area is approximated. The mean annual actual evapotranspiration for the whole study area is then computed by the following equation.

$$
\mathrm{AET}_{\mathrm{T}}=\sum_{i=0}^{n} \frac{A E T i * A i}{A} \quad \text {------------------------ Equation (6) }
$$

Where,

$\mathrm{AET}_{\mathrm{T}}$ - Total actual evapotranspiration

$\mathrm{AET}_{\mathrm{i}}$ - Annual actual evapotranspiration for each soil type \& respective land use (Table 12)

$A_{i}$ - Area of each soil type with its respective land use

A - Total catchment area

\subsection{Runoff}

\subsubsection{Runoff Coefficient or Rational Method (Chow et al., 1988)}

In this method, runoff is considered to be strongly dependent on the rainfall amount and intensity and the runoff environment. The topography, vegetation, land use/land cover and soil infiltration capacity are the parameters used to determine the runoff coefficient. The annual yield of a drainage basin is then determined based on the runoff coefficient, the annual precipitation and the size of the catchment area. The Tigray Water Resource Bureau has estimated the runoff coefficient of the Tekeze basin during the feasibility study of the Serenta Dam in Tselemti Woreda (Runoff Coeff. Tekeze basin, i.e. $\mathrm{C}=0.25$ ). As the study area is found in the same basin with this dam site and has similar governing catchment characteristics, this runoff coefficient is used to estimate the surface runoff in the study area.

$$
\mathrm{Q}=\text { C.P.A }
$$
Equation (7)

Where,

$\mathrm{Q}=\operatorname{Runoff}\left(\mathrm{m}^{3}\right)$

$\mathrm{C}=$ Coefficient of runoff;

$\mathrm{A}=$ Catchment area in $\mathrm{m}^{2}$

$\mathrm{P}=$ rainfall in $\mathrm{mm}$ calculated from Isohyetal method

\subsection{Groundwater Recharge Estimation}

The significant parameter in terms of groundwater resource evaluation is the long-term average recharge which is usually considered as the maximum available groundwater resource (Brassington, 1988). Considering the fact that in unconfined aquifers the groundwater table is a subdue replica of the surface morphology, the boundary of the catchment area is taken as no flow boundary in the aquifer of the study area. And assuming that water leaves the study area only in the form of surface runoff and evapotranspiration, the water balance equation for the study area becomes as follows.

$$
\boldsymbol{R}=\boldsymbol{P}-(\boldsymbol{A E T}+\boldsymbol{Q})
$$

Where, $\mathrm{R}$ is estimated recharge to the groundwater 


\subsection{Annual Groundwater Budget}

Assuming the study area is at its steady state condition i.e. the inflow and outflow components are at equilibrium on annual base, the simplified groundwater budget equation is:-

$$
\text { Inflow }=\text { out flow } \pm \text { change in storage -------------------------- Equation (9) }
$$

The general form of the water balance of a given basin or catchment can also be given by:

$$
P+I+A i+Q i=R o+A E T+Q o+W \pm \Delta S
$$

Where,

$\mathrm{P}=$ precipitation $\mathrm{I}=$ infiltration from surface water $\mathrm{Ai}=$ Artificial recharge

$\mathrm{Qi}=$ groundwater inflow $\quad \mathrm{Ro}=$ surface runoff $\quad \mathrm{AET}=$ actual evapotranspiration

$\mathrm{Qo}=$ groundwater outflow $\mathrm{W}=$ withdrawal and $\pm \Delta \mathrm{S}=$ change in storage

Assumptions have been made to derivate the water balance equation for the study area;

- Since there is no significant surface water in the study area, net change of the soil moisture due to surface water infiltration to the groundwater is assumed to be zero.

- The groundwater divide coincides with the surface water divide and hence there is no groundwater inflow.

- The groundwater outflow from the area is equal to baseflow on the streams.

- As there is no water imported from the nearby areas for irrigation or other purpose artificially from nearby areas artificial water recharge is taken to be zero. Therefore; the above Annual Net Groundwater Budget is reduced to the following equation:

$$
\pm \Delta \mathrm{s}=\mathrm{P}-\mathrm{Ro}-\mathrm{AET}-\mathrm{W}-\mathrm{Qo}
$$

The total annual groundwater out flow from the study area as springs and total annual abstraction from the area were estimated based on the available secondary data and by conducting field measurements. Field testing of discharge from eleven sampled irrigation hand dug wells (sampled from three different lithologies) was conducted by using dewatering pumps. The abstraction for the domestic water supply from the hand pump fitted wells in the area is calculated by using the known pumping rate of the hand pumps and operational time of the pumps per day. Spring discharges are also measured in the field by using the volumetric method.

The average size of land being irrigated by one hand dug well is estimated by measuring areal size of representative irrigated plots in the area. The annual net average groundwater recharge of the catchment is calculated by putting the input and output parameters estimated by the methods described above in the water balance equation of the 
area. The soil and land use/land cover maps were also used in conjunction with the above mentioned meteorological data to estimate the groundwater balance.

\subsection{Aquifer Properties}

After pumping all the water in the large diameter wells and monitoring the rate of recovery in the wells, it is possible to get an estimated value for the hydraulic conductivity $(\mathrm{K})$ of an aquifer (Mace, 1999; Rupp et al., 2001). This method can also be used to predict theoretical well yields and to quantify spatial water availability distribution in the aquifers in close vicinity to the wells. In this study: three hand dug wells from the highly weathered basalt; six hand dug wells from the highly weathered mudstone - sandstone intercalation and two hand dug wells from the slightly weathered and fractured metavolcanics were sampled for the recovery tests.

Groundwater level contour map is produced in the ArcGIS environment based on the static water level data collected from springs and hand dug wells. To understand the wells' expected and observed performance (i.e.; capacity to irrigate, seasonality and economic impact), the management approach done by the beneficiaries to sustain the wells formal and informal discussions and interviews was done with local community members, administrators and extension agents.

The geological and hydrogeological descriptions and maps in this study are made by using secondary data from previous works and by undertaking field traverse to confirm lithological contacts and to describe the rock types, their texture, and degree of weathering and geological structures. The collected primary or secondary data have been processed using relevant software like ArcGIS, Aqua chem., Erdas, CROPWAT 8.0, NEW-LOCLIME etc. and finally the results are presented in the form of maps, figures, graphs and tables in ease for understanding and interpretation.

\section{RESULT AND DISCUSSION}

\subsection{Geology}

\subsubsection{Local Geology}

The geology of the study area from bottom-up is constituted by basement, sandstonemudstone and the basalt rocks (Fig 3). The basalt is characterized by its high degree of weathering and fracturing; it has vesicular and amygdaloidal nature and occasionally with paleosol. This rock formation forms the Koyetsa ridge in the upstream side (recharge area) of the watershed. Below the basalt is the lateritic sandstone-mudstone intercalation which is also highly weathered and fractured (Fig 3). This rock formation covers the middle and lower 
gentle/flat sloping part of the study area. In most of the area this rock formation is covered with talus and alluvial sediments. The thicknesses of these lose/unconsolidated sediments on the top of the sandstone-mudstone are higher near to the foot of the Koyetsa ridge and decreases downstream. Most irrigation dug wells are penetrated in the alluvium and the sandstone-mudstone intercalation. Below sandstone-mudstone; the downstream reach of the catchment is mainly comprised of basement rocks (metavolcanics) which are moderately weathered and fractured. There are also shallow boreholes and hand dug wells taping groundwater for domestic water supply from the localized aquifers in these rocks.

Table 2. Areal coverage of the lithological units.

\begin{tabular}{|lll|}
\hline Lithological units & Areal coverage in $\mathbf{k m}^{\mathbf{2}}$ & Percentage (\%) \\
\hline Basalt & 10.714 & 31.136 \\
\hline Mudstone - Sandstone intercalation & 20.0 & 58.123 \\
\hline Metavolcanic (basement) & 4.286 & 10.741 \\
\hline Total & 34.41 & 100 \\
\hline
\end{tabular}

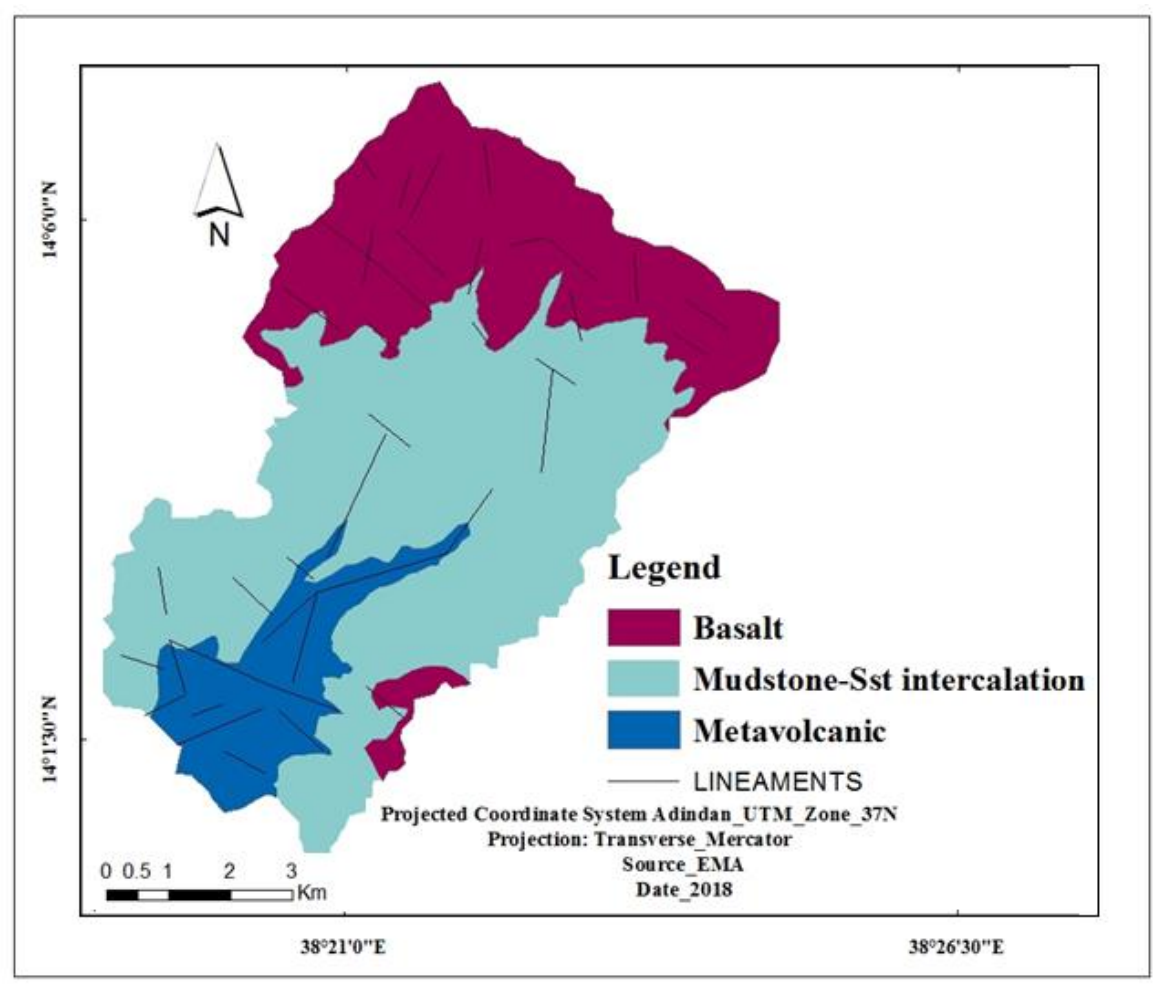

Figure 3. Geological map of the study area.

\subsubsection{Basalt}

The basalt, as presented in the map, occupies mostly the northern and southeastern parts of the study area. The thick succession of the stratified basaltic unit is developed along the chain of ridges running from northeastern parts of Shire Endassilasie town to the right north of the 
study area. The basaltic terrain, serves as the main recharging unit. Surface and sub-surface data shows, weathering (exfoliation and spheroidal) of this formation develops openings of high permeability for groundwater recharge.

\subsubsection{Sandstone-Mudstone Intercalation}

The rocks of this formation overly the basement rocks and occupy the central part of the study area. They consists of mottled and variegated silicified mudstone, grayish to reddish siltstone, whitish-reddish medium to fine grained sandstone, and thin beds of conglomeratic basal sandstone. Eventhough, the unit thickness varies from place to place as observed in the field and from the wells' logs stratigraphy, the thickness of the sandstone is not more than $30 \mathrm{~m}$.

\subsubsection{Metavolcanic Rocks}

These are basically composed of different varieties, the agglomerates contain fine grained groundmass with lithic fragments of basic and acidic composition. Epidotization is common, quartz stringers and veins are abundant. These rocks are grey in color, hard, compact, massive to moderately fractured, and moderately weathered.

\subsection{Hydrometeorology}

Long term measurements of meteorological parameters such as precipitation, temperature, wind speed, relative humidity, sunshine hours, evaporation, atmospheric pressure and radiation are essential to understand the atmospheric phenomena so as to assess the hydrogeological conditions of a given catchment or water basin. In the study area, meteorological data were collected from four vicinity meteorological stations, Shire, Endabaguna, Debrekerbe, and Selekleka (Table 3 and Fig 1).

Table 3. Location of Meteorological Stations and data recording years.

\begin{tabular}{|llllll|}
\hline S. No. & Meteorological & \multicolumn{3}{c}{ UTM Location } & \multirow{2}{*}{ Recording years } \\
\cline { 2 - 5 } & stations & Easting & Northing & Elevation & \\
\hline 1 & Shire & 423215 & 1559328 & 1910 & 20 years \\
\hline 2 & Endabaguna & 400280 & 1555355 & 1880 & 15 years \\
\hline 3 & Debrekerbe & 441047 & 1542517 & 1976 & 3 years \\
\hline 4 & Selekleka & 443254 & 1560265 & 2180 & 16 years \\
\hline
\end{tabular}

Shire meteorological station is the class-A station type in the study area that measures all the meteorological elements whereas the other stations are lower class stations which record only rainfall and temperature.

The principal rainy season in the study area like other parts of north Ethiopia is the summer season (June to September). From the precipitation records in the four stations of the 
vicinity of the study area, the highest amount recorded were in the months of July and August (341 $\mathrm{mm}$ and $329.63 \mathrm{~mm}$, respectively), and around $60 \%$ of the total precipitation in the area has fallen in these two months (Table 4 and Fig 4).

Table 4. Monthly precipitation percentage contribution to the annual rainfall.

\begin{tabular}{|lllllllllllll|}
\hline Months & Jan & Feb & Mar & Apr & May & Jun & Jul & Aug & Sept & Oct & Nov & Dec \\
\hline Mean RF, mm & 6.2 & 0.9 & 13.8 & 25.4 & 43.6 & 151.7 & 341.2 & 329.6 & 173.7 & 37.5 & 7.5 & 2 \\
\hline Contribution, \% & 0.6 & 0.1 & 1.2 & 2.3 & 3.9 & 13.5 & 30.4 & 29.4 & 15.8 & 3.3 & 0.7 & 0.2 \\
\hline
\end{tabular}

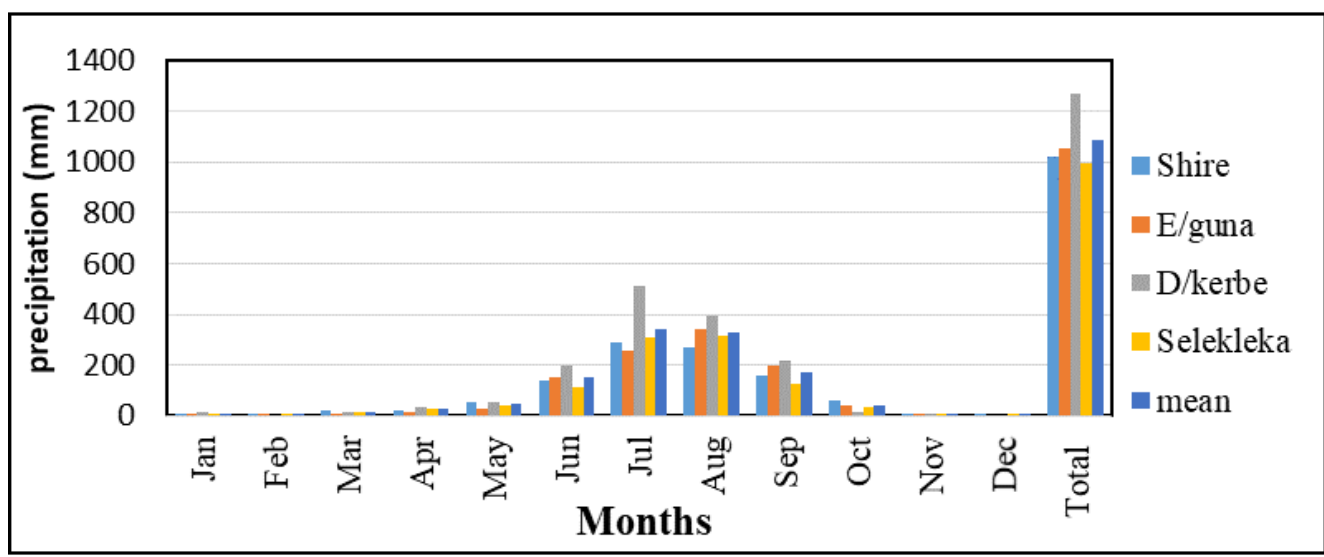

Figure 4. Long term mean monthly precipitation of the stations.

Table 5. Calculated annual precipitation using Isohyetal Method.

\begin{tabular}{|c|c|c|c|c|c|}
\hline ID. & Isohyet (mm) & Pi average $(\mathrm{mm})$ & $A i\left(k^{2}\right)$ & $A i / A t(\%)$ & $P i(A i / A t), m m$ \\
\hline 1 & 1058-1089 & 1073.785 & 4.5211 & 13.139 & 141.085 \\
\hline 2 & 1089-1119 & 1104.343 & 12.7327 & 37.003 & 408.640 \\
\hline 3 & $1119-1150$ & 1134.897 & 9.3818 & 27.265 & 309.429 \\
\hline 4 & $1150-1180$ & 1165.4505 & 7.0767 & 20.566 & 239.687 \\
\hline 5 & $1180-1212$ & 1196.006 & 0.6878 & 1.999 & 23.908 \\
\hline & & & & Total & 1123 \\
\hline
\end{tabular}

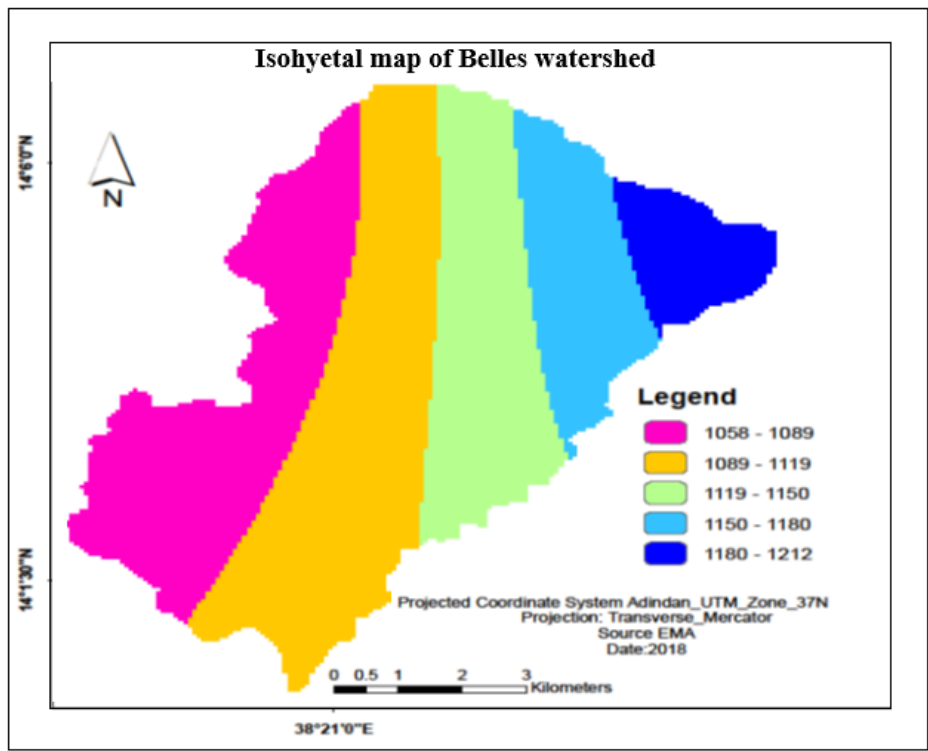

Figure 5. Isohyetal map of the study area. 
The mean annual precipitation for the study area is estimated by using the isohyetal method (1123 mm/year). The estimate from the isohyetal method (Fig 5 and Table 5) is considered for further computations of water balance in this study as it considers the orographic effect. In the study area, the mean monthly temperature ranges between $19.4^{\circ} \mathrm{C}$ and $23.5^{\circ} \mathrm{C}$. The high level of variability of the rainfall in the months of the year and among the seasons is discussed in the previous sections. In addition, the analysis of long-term rainfall data from the stations indicates that the rainfall pattern among the years is very erratic (Fig 6). Therefore, rain-fed farming which is characteristic to the area is highly susceptible to unexpected moisture stress conditions.

Table 6. Long term mean annual temperature of the stations.

\begin{tabular}{|c|c|c|c|c|c|c|c|c|c|c|c|c|c|}
\hline \multirow{2}{*}{$T\left({ }^{0} \mathrm{C}\right)$} & \multicolumn{13}{|c|}{ Months of the year } \\
\hline & $\overline{\mathrm{Jan}}$ & Feb & Mar & Apr & May & Jun & Jul & Aug & Sep & Oct & Nov & Dec & Annual \\
\hline Ave. max & 28.12 & 28.72 & 29.65 & 30.12 & 30.28 & 28.11 & 24.87 & 24.20 & 25.87 & 27.33 & 27.26 & 26.57 & 27.59 \\
\hline Ave. min & 12.57 & 14.27 & 15.13 & 16.81 & 17.33 & 15.25 & 14.29 & 14.30 & 13.74 & 14.67 & 14.18 & 12.23 & 14.40 \\
\hline & 0.35 & 1.49 & 2.3 & 23.46 & 3.8 & 21.68 & 19.58 & 19.25 & 19.80 & 21.00 & 20.72 & 19.40 & 21.00 \\
\hline
\end{tabular}

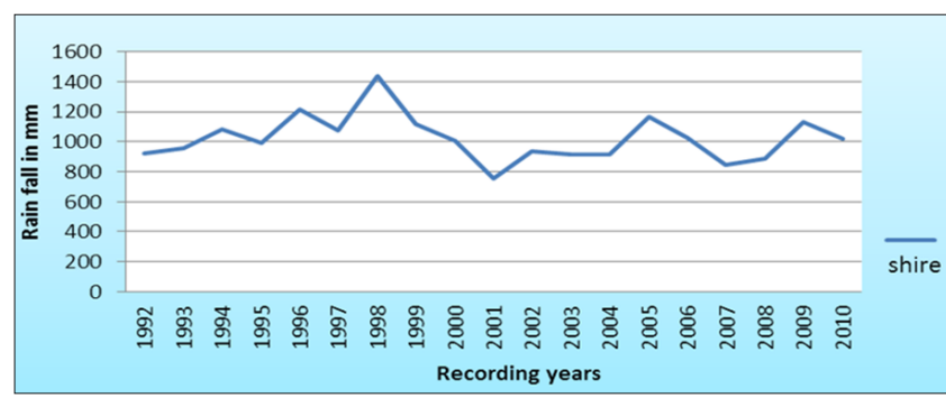

Figure 6. Mean annual trend of Shire station.

In the study area, the maximum amount of relative humidity is recorded during rainy season (August, July, September and June). During summer, since atmosphere holds water vapor near to its maximum holding capacity results in high relative humidity, $79 \%$ in August and minimum $30 \%$ in February (Fig 7).

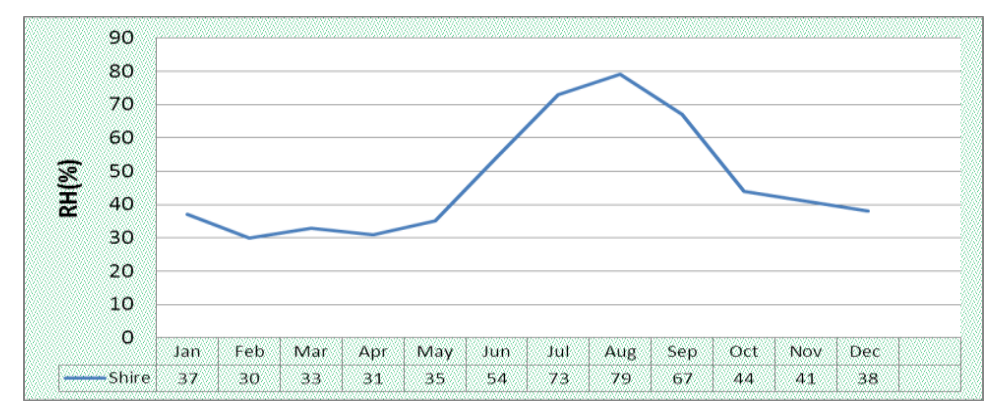

Figure 7. Trend of Mean monthly average relative humidity. 
The maximum wind speed in the study area is observed in April $(2.1 \mathrm{~m} / \mathrm{s})$ whereas, the least is recorded in September $(1.2 \mathrm{~m} / \mathrm{s})$. The mean monthly wind speed is lower in the summer season and early months of the dry season (Fig 8).

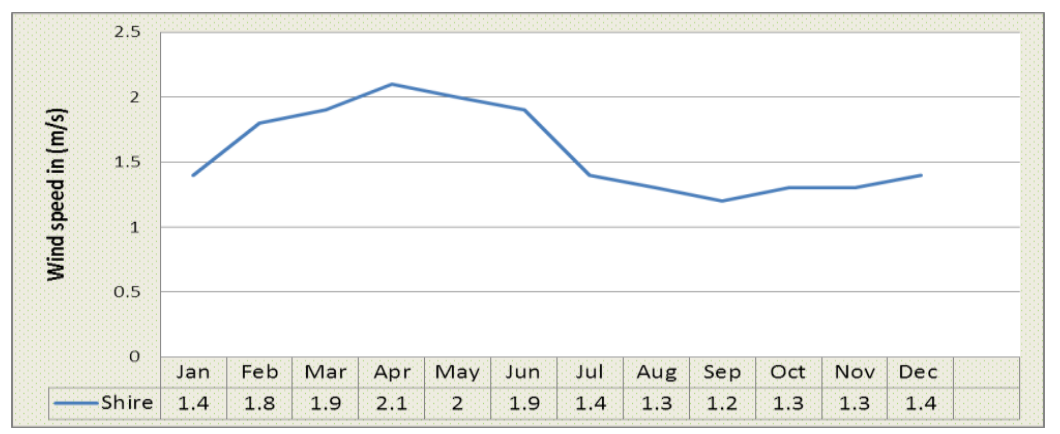

Figure 8. Mean monthly wind speed of the study area.

The bright sunshine hours is measured from midnight to midnight. A further indication of good weather is the percentage of daylight Hours with bright sunshine. Even though evapotranspiration could take place without interruption during both day and night, the process becomes more active under direct radiation from the sun.

The maximum, minimum and the average sunshine hours for the study area is around 10.3, 3.9 and 8 hours respectively. Seasonally; it is low in the summer season but higher in the dry season (Fig 9).

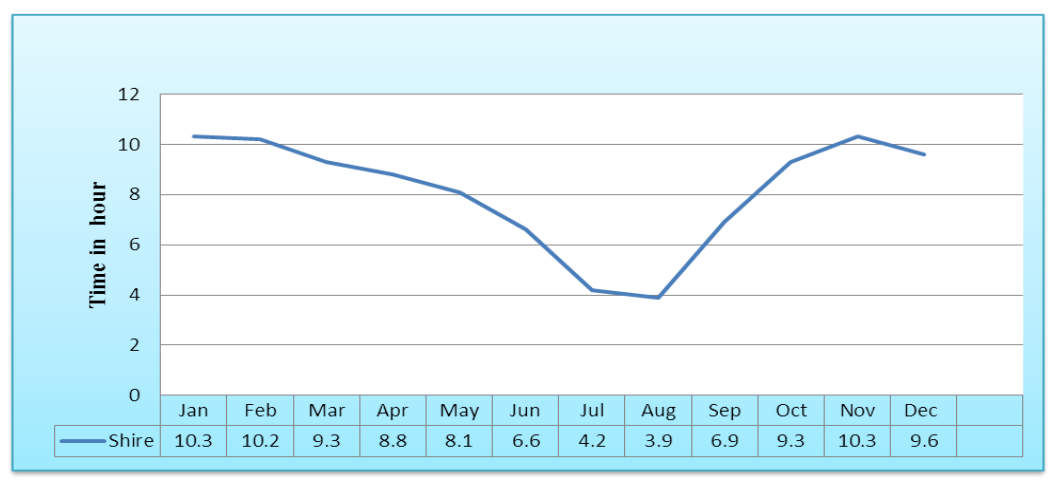

Figure 9. Mean monthly sun shine hour.

\subsection{Evapotranspiration, Runoff and Groundwater Recharge}

Based on Equations 1 and 2 the mean monthly and mean annual PET are computed and the result is shown in table 7. Accordingly, the mean annual PET is estimated to be 1484 $\mathrm{mm} /$ year (Table 7). By using $\mathrm{P}=1122.749 \mathrm{~mm}$ and $\mathrm{T}=21{ }^{\circ} \mathrm{C}$ in the equations 3 and 4 (Turc, 1961 method), the value estimated for the annual AET in the study area is $501.7 \mathrm{~mm} /$ year. The mean monthly and mean annual AET values obtained by using the Crowe (1971) method (equation 5) are given in table 8. Annual AET obtained using this method is $568.8 \mathrm{~mm}$. 
Table 7. Mean monthly and mean annual PET obtained from Thornthwaite (1948) method.

\begin{tabular}{|llllllllllllll|}
\hline Item & Jan & Feb & Mar & Apr & May & Jun & Jul & Aug & Sep & Oct & Nov & Dec & Annual \\
\hline $\mathrm{Tm}\left({ }^{\circ} \mathrm{c}\right)$ & 19.9 & 20.8 & 22 & 23 & 23.2 & 21.4 & 19.4 & 19.0 & 19.5 & 20.4 & 20.3 & 18.5 & 20.62 \\
\hline $\mathrm{N}$ & 11.6 & 11.8 & 12 & 12.3 & 12.6 & 13 & 12.6 & 12.4 & 12.1 & 12 & 12 & 11.5 & 12.1 \\
\hline $\mathrm{N}_{\mathrm{m}}$ & 0.97 & 0.98 & 1.00 & 1.03 & 1.05 & 1.08 & 1.05 & 1.03 & 1.01 & 1.00 & 1.00 & 0.96 & 12.16 \\
\hline $\mathrm{I}_{\mathrm{m}}$ & 7.94 & 8.49 & 9.23 & 9.87 & 9.99 & 8.88 & 7.64 & 7.43 & 7.70 & 8.27 & 8.13 & 7.12 & 100.7 \\
\hline $\mathrm{a}$ & 0.63 & 0.64 & 0.65 & 0.66 & 0.66 & 0.64 & 0.62 & 0.63 & 0.62 & 0.63 & 0.63 & 0.61 & 0.64 \\
\hline PET, mm & 118 & 120.7 & 124.8 & 131.8 & 134.4 & 133.1 & 124.3 & 118.7 & 119. & 124. & 121. & 112.1 & $\mathbf{1 4 8 4}$ \\
\hline
\end{tabular}

Table 8. Monthly AET calculated by Crowe (1971) method.

\begin{tabular}{|lllllllllllllll|}
\hline Item & \multicolumn{1}{c|}{} & \multicolumn{10}{c|}{ Months of the year } & & \multicolumn{1}{c|}{ AET } \\
\hline & Jan & Feb & Mar & Apr & May & Jun & Jul & Aug & Sep & Oct & Nov & Dec & annual \\
\hline $\boldsymbol{T},{ }^{\boldsymbol{}} \boldsymbol{k}$ & 393.1 & 394 & 395.2 & 396.2 & 396.3 & 394.6 & 392.6 & 392.2 & 392.7 & 393.6 & 393.4 & 391.7 & 393.8 \\
\hline AET & 43.7 & 43.8 & 43.9 & 44.0 & 44.0 & 43.8 & 43.6 & 43.6 & 43.6 & 43.7 & 43.7 & 43.5 & $\mathbf{5 6 8 . 8}$ \\
\hline
\end{tabular}

The third method that was employed to estimate the annual AET in the study area was the Soil Water Balance Method (Thornthwaite and Mather, 1957). Based on the assumptions made under section 3.1.2.3 and the computations in the tables 9, 10 and 11, the AET for each soil type with its respective land use in the study area are approximated. The mean annual actual evapotranspiration for the study area is then computed by averaging these estimates using equation 6 . The value obtained is $814 \mathrm{~mm} /$ year (Table 12).

Table 9. AET for Soil texture - silt clay, AWC $=250 \mathrm{~mm}$, Vegetation deep rooted, crops such as alfalfa, pasture grasses, shrubs, etc.

\begin{tabular}{|c|c|c|c|c|c|c|c|c|c|c|c|c|}
\hline \multirow{2}{*}{$\begin{array}{l}\text { Value } \\
\text { (mm) }\end{array}$} & \multicolumn{12}{|c|}{ Months } \\
\hline & Jan & Feb & Mar & Apr & May & June & July & Aug & Sep & Oct & Nov & Dec \\
\hline $\mathrm{P}$ & 6.18 & 0.91 & 13.83 & 25.38 & 43.58 & 151.67 & 341.15 & 329.63 & 173.65 & 37.525 & 7.453 & 2 \\
\hline PET & 118.0 & 120.7 & 124.8 & 131.8 & 134.4 & 133.1 & 124.3 & 118.7 & 119.0 & 124.0 & 121.0 & 112.1 \\
\hline P-PET & -111.8 & -119.8 & -111.0 & -106.4 & -90.8 & 18.6 & 216.9 & 210.9 & 54.7 & -86.5 & -113.5 & -110.1 \\
\hline ACPWL & -421.8 & -541.7 & -652.8 & -759.8 & -849.8 & 0 & 0 & 0 & 0 & -86.5 & -200 & -310.1 \\
\hline SM & 46.3 & 28.7 & 26.6 & 18.4 & 4.6 & 23.2 & 240.1 & 250 & 250 & 176.8 & 112.3 & 72.34 \\
\hline$\Delta \mathrm{SM}$ & -26.04 & -17.6 & -2.1 & -8.2 & -13.8 & 18.6 & 216.9 & 9.9 & 0 & -73.2 & -64.5 & -40 \\
\hline AET & 32.22 & 18.51 & 15.9 & 33.58 & 57.38 & 133.1 & 124.3 & 118.7 & 119 & 110.73 & 71.95 & 42 \\
\hline SMD & 85.8 & 102.2 & 109 & 98.22 & 77.0 & 0 & 0 & 0 & 0 & 13.27 & 49.05 & 70.1 \\
\hline
\end{tabular}

Where,

$P=$ the mean monthly rainfall of the catchment obtained from Isohyetal method.

$P E T=$ the potential evapotranspiration calculated from Thornthwaite and Mather method.

$P$-PET $=$ is the difference between precipitation and potential evapotranspiration. Positive values indicate the addition of moisture to the soil while the negative values show the monthly moisture demand by the vegetation.

$A c c P W L=$ Accumulated potential water loss (the sum of the negatives of P-PET starting from the dry month to the beginning of wet month).

$M A W C=$ Maximum available water capacity

$S M=$ soil moisture; the soil moisture content during the dry months is calculated using accumulated potential water loss by the following formula;

$S M=A W C * \exp \left[-\left(\frac{\mathrm{ACPWL}}{\mathrm{AWC}}\right)\right]$

Soil moisture values for each wet month are obtained by adding the excess of rainfall of the current month to the soil moisture of the month before. But, the sum may or may not exceed 
the MAWC. If the soil moisture value exceeds the available water capacity of the root zone, the excess moisture is recorded as moisture surplus.

$\Delta S M=$ Difference in soil moisture is the difference between precipitation and actual evapotranspiration of each month. Or $\Delta \mathrm{SM}=\mathrm{S}_{\mathrm{m}}-\mathrm{S}_{\mathrm{m}-1}$. The positive values indicate the soil moisture recharge.

If $\mathrm{Pm}>\mathrm{PETm}$, then AETm $=$ PETm; Otherwise AETm $=\mathrm{Pm}+|\Delta \mathrm{SMm}|$. When the potential evapotranspiration exceeds the precipitation amount, the actual evapotranspiration will be equal to the sum of precipitation and the amount of soil moisture withdrawn from storage.

$S M D=$ the soil moisture deficit is values calculated easily by subtracting the actual evapotranspiration from the potential evapotranspiration (PET-AET). The annual AET calculated for the silt clay texture is equal to $877 \mathrm{~mm}$.

Table 10. AET for clay soil with an available water capacity of $75 \mathrm{~mm}$ (Vegetation is shallow rooted crops such as peace, spinach, beats, carrot etc., the annual AET calculated for the soil with the clay texture and shallow rooted crops is equal to $716 \mathrm{~mm} / \mathrm{year}$ ).

\begin{tabular}{|c|c|c|c|c|c|c|c|c|c|c|c|c|}
\hline \multirow{2}{*}{$\begin{array}{l}\text { Value } \\
\mathrm{mm}\end{array}$} & \multicolumn{12}{|c|}{ Months } \\
\hline & Jan & Feb & Mar & $A p r$ & May & June & July & Aug & Sep & Oct & Nov & Dec \\
\hline $\mathrm{P}$ & 6.18 & 0.91 & 13.83 & 25.38 & 43.58 & 151.67 & 341.15 & 329.63 & 173.65 & 37.525 & 7.453 & 2 \\
\hline PET & 118.0 & 120.7 & 124.8 & 131.8 & 134.4 & 133.1 & 124.3 & 118.7 & 119. & 124. & 121. & 112.1 \\
\hline P-PET & -111.8 & -119.8 & -111.0 & -106.4 & -90.8 & 18.6 & 216.9 & 210.9 & 54.7 & -86.5 & -113.5 & -110.1 \\
\hline ACPWL & -421.8 & -541.7 & -652.8 & $\begin{array}{l}-759.8 \\
\end{array}$ & -849.8 & 0 & 0 & 0 & 0 & -86.5 & -200 & -310.1 \\
\hline SM & 5.65 & 2.65 & 0.2 & 0.05 & 0.01 & 18.7 & 75 & 75 & 75 & 23.7 & 5.3 & 1.2 \\
\hline$\Delta \mathrm{SM}$ & -4.45 & -3 & -2.45 & -0.15 & -0.04 & 18.69 & 56.3 & 0 & 0 & -51.3 & -18.4 & -4.1 \\
\hline AET & 10.63 & 3.91 & 16.3 & 25.53 & 43.62 & 133.1 & 124.3 & 118.7 & 119 & 88.8 & 26 & 6.1 \\
\hline SMD & 107.37 & 116.8 & 108.5 & 106.3 & 90.78 & 0 & 0 & 0 & 0 & 35.2 & 95 & 106 \\
\hline
\end{tabular}

Table 11. Soil type is clay loam with an available water capacity of $200 \mathrm{~mm}$ (Vegetation is moderately-deep rooted crops such as grasses, shrubs, sorghum, maize etc., the annual AET for the clay loam soil texture with moderate/deep rooted crops is approximated to be $829 \mathrm{~mm} /$ year).

\begin{tabular}{|c|c|c|c|c|c|c|c|c|c|c|c|c|}
\hline \multirow[t]{2}{*}{$m m$} & \multicolumn{12}{|c|}{ Months } \\
\hline & Jan & Feb & Mar & Apr & May & June & July & Aug & Sep & Oct & Nov & Dec \\
\hline $\mathrm{P}$ & 6.18 & 0.91 & 13.83 & 25.38 & 43.58 & 151.6 & 341.2 & 329.63 & 173.65 & 37.525 & 7.453 & 2 \\
\hline PET & 118.0 & 120.7 & 124.8 & 131.8 & 134.4 & 133.1 & 124.3 & 118.7 & 119. & 124. & 121. & 112.1 \\
\hline P-PET & -111.8 & -119.8 & -111.0 & -106.4 & -90.8 & 18.6 & 216.9 & 210.9 & 54.7 & -86.5 & -113.5 & -110.1 \\
\hline ACPWL & -421.8 & -541.7 & -652.8 & -759.8 & -849.8 & 0 & 0 & 0 & 0 & -86.5 & -200 & -310.1 \\
\hline SM & 24.3 & 13.4 & 7.7 & 4.5 & 2.87 & 21.5 & 200 & 200 & 200 & 129.8 & 73.6 & 42.43 \\
\hline$\Delta \mathrm{SM}$ & -18.13 & -10.9 & -5.7 & -3.2 & -1.63 & 18.63 & 178.5 & 0 & 0 & 16.3 & 57.3 & 78.93 \\
\hline AET & 24.31 & 12 & 19.53 & 28.58 & 45.21 & 133.1 & 124.3 & 118.7 & 119 & 107.7 & 63.7 & 33.17 \\
\hline SMD & 93.7 & 108.7 & 105.3 & 103.2 & 89.2 & 0 & 0 & 0 & 0 & 16.3 & 57.3 & 78.93 \\
\hline
\end{tabular}

Table 12. Weighted average annual AET of the study area by Thornthwaite and Mather (1957) soil water balance method.

\begin{tabular}{|lllll|}
\hline Soil Texture & Land use /Land cover & AWC, $\mathbf{m m}$ & Areal \% & AET, $\mathbf{m m}$ \\
\hline Clay & $\begin{array}{l}\text { Moderately cultivated crops of } \\
\text { shallow rooted variety like onion }\end{array}$ & 75 & 42.1 & 877 \\
\hline Clay loam & $\begin{array}{l}\text { Moderately to intensively cultivated } \\
\text { cereal crops (moderately deep rooted }\end{array}$ & 200 & 31.24 & 716 \\
\hline Silt clay & $\begin{array}{l}\text { Not Intensively cultivated with various } \\
\text { crops and scattered shrubs and grass }\end{array}$ & 250 & 26.62 & 829 \\
\hline Weighted average & & & $\mathbf{8 1 4}$ \\
\hline
\end{tabular}


The methods of Turc (1961), and Crowe (1971) have resulted in significantly underestimated values for AET for the study area as compared to the Soil Water Balance method of Thornthwaite and Mather (1957). Due to the fact that Thornthwaite and Mather (1957) method considers more variables (land use/land cover, soil texture and meteorological variables), the AET value ( $814 \mathrm{~mm} / \mathrm{year}$ ) obtained computed by this method is considered to be reliable for the water budget computations in this study.

Based on the Rational method (Chow et al., 1988) discussed in section 3.2.1, the annual runoff of 9,658,456.9 cubic meters/year or $280 \mathrm{~mm} / \mathrm{year}$ is estimated using equation 7 $\left(\mathrm{C}=0.25, \mathrm{P}=1.123 \mathrm{~m} /\right.$ year, $\left.\mathrm{A}=34,402,340 \mathrm{~m}^{2}\right)$. Finally, the mean annual groundwater recharge for the study area is estimated as $29 \mathrm{~mm} / \mathrm{year}$ using equation $8(\mathrm{P}=1123 \mathrm{~mm} / \mathrm{year}$, $\mathrm{Q}=280 \mathrm{~mm} /$ year, $\mathrm{AET}=814 \mathrm{~mm} /$ year ).

\subsection{Annual Groundwater Abstraction (W)}

The total annual discharge from the groundwater reservoir is the summation of annual base flow and total annual abstraction of water through different mechanisms for the economic benefit and life habit of the society (Freeze and cherry, 1979). Principally, groundwater discharge is defined as the removal of water from saturated zone through natural or artificial processes. In the study area, the first means for the emergence of groundwater naturally to the surface is in the form of baseflow while the second means is groundwater discharge by artificial human intervention through wells for different purposes. According to the data obtained from the Woreda water office, field observation, and taking related national standards and guidelines an attempt is made to determine the groundwater that is annually extracted for various uses by 15,965 population and 3302 households (Samia, 2007). Estimated demand is 0.13 million cubic meters/year, as per the standard domestic water demand for rural areas (Tigray Bureau of Water Resource (TBoWR) (i.e. 20 lit/capita/day).

According to Woreda Water Resource, Mine and Energy and Agriculture and Rural Development Offices' annual report (2017/18), the dominant crops grown in the study area by irrigation from groundwater are maize (141.54 ha), onion (40.55 ha), bean (101.95 ha) and tomato $(5.97 \mathrm{ha})$. A total about 290.01 ha of land was being irrigated in the dry season. Using the Loclime and CROPWAT 8.0 software, the average actual crop water requirement for the study area is approximated to be $0.6 \mathrm{lit} / \mathrm{sec} / \mathrm{ha}$ and according to the TBoWR the regional efficiency of water in irrigation is $50 \%$. The average growing period until harvest is 3.25 months. Watering time is 10 days/month, and average groundwater pumping 2.5 hours/day. Accordingly, the total annual groundwater abstraction for irrigation is estimated to be 0.24 million cubic meters/year from around 278 hand dug wells with a maximum depth of $10 \mathrm{~m}$. 
According to Woreda Water Resource, Mine and Energy and Agriculture and Rural Development Offices' annual report (2016), there are about 92914 different types of domestic animals (7384 sheep, 20263 goats, 27255 cattle, 1483 equines and 36529 poultry). Based on the developed national guidelines of daily water requirements for Livestock by MoARD (2008), the average daily water requirement is: for Cattle (35 lit), Equines (20 lit), Sheep (4.5 lit), Goat (4.5 lit), and poultry (0.1 lit). Considering the type and total animal population in the area; the groundwater withdrawal for livestock is averagely estimated as 0.14 million cubic meters per year. And the base flow on streams that is measured by the Woreda water office during the construction of irrigation structures and checked during the field work (by measuring on monthly basis using the float method and taking the average) is around 24 lit/sec and annually it becomes 0.36 million cubic meters/year. Therefore; the total annual groundwater discharge (W) from the study area in the form of baseflow and for human, livestock and irrigation uses is estimated to be 0.87 million cubic meters $(25 \mathrm{~mm})$ per year.

Based on equation 11, the annual net change in groundwater storage resulted to a value of $4 \mathrm{~mm}$, which should be zero for the hydrologic system which was assumed to be under steady-state condition. The $4 \mathrm{~mm}$, therefore, can be accounted for the groundwater outflow through deeper groundwater flow in the fractured mudstone - sandstone intercalation, which was ignored in the water balance calculation. Here it should be noted that the groundwater recharge rate is expected to remain constant while the total annual groundwater discharge is expected to increase from year to year. This relation when projected over a long period may result in negative groundwater budget which can result in depletion of groundwater (lowering of groundwater levels), reduced baseflow to streams \& deterioration of water quality. Therefore, it is recommended that water saving irrigation technologies should be used (if there is a need of increasing the irrigation area) rather than increasing the number of wells. In addition, groundwater recharge enhancement structures such as trenches, percolation ponds and check dams should be systematically constructed in scientifically selected localities.

\subsection{Hydraulic Conductivity}

According to Rupp et al. (2001), the recovery values between time $\boldsymbol{t}_{25}$ when drawdown is $\mathbf{y} 25$ (the water level recovers approximately $25 \%$ of total drawdown) and time $\mathbf{t 7 5}$ when drawdown is $\mathbf{y} 75$ (the water level recovered approximately 75\%) is considered to estimate the hydraulic conductivity (Fig 10). This is because of the assumption that the recovered water below $25 \%$ can be from the effect of well storage and that of above $75 \%$ can have an influence of aquifer very far from the well. 


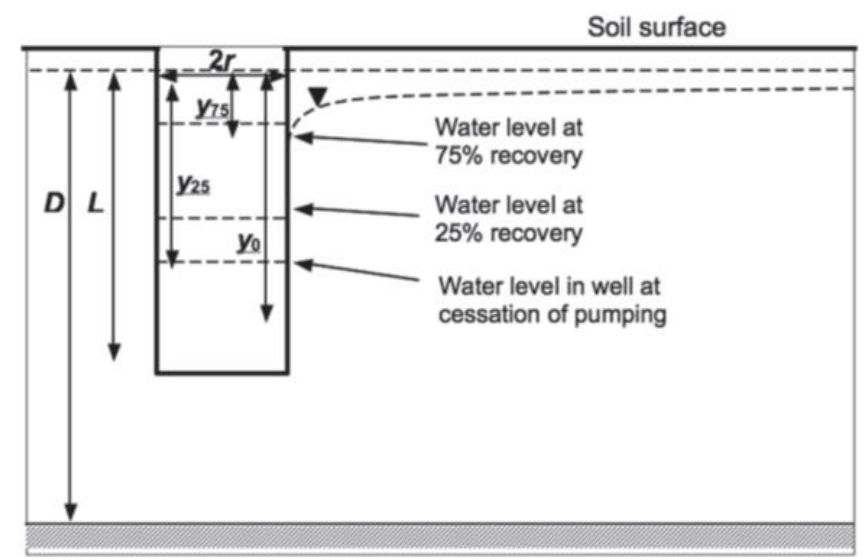

Figure 10. Schematic of a large-diameter pumping well.

Then hydraulic conductivity $(\mathrm{K})$ can be estimated from the equation below which is valid for $2 \leq L / r \leq 20$.

$$
\mathrm{K}=\frac{\mathrm{r}^{2} \mathrm{R}}{2 \mathrm{~L}\left(\mathrm{t}_{75}-\mathrm{t}_{25}\right)} \ln \left(\frac{\mathrm{Y}_{25}}{\mathrm{Y}_{75}}\right)
$$

Where,

$r$ - Well radius $(\mathrm{m})$

$L$ - Distance from the phreatic water level to the bottom of the well (m),

$t_{25}$ - time for the well to recover $25 \%$ of its initial water level (min),

$t_{75}$ - time for the well to recover $75 \%$ of its initial water level (min),

$y_{25}$ - distance from the phreatic water level to the $25 \%$ recovery level (m),

$y_{75}$-distance from the phreatic water level to the $75 \%$ recovery level $(\mathrm{m})$, and

$R$-the effective radius where head differences are dissipated (m) (Bouwer and Rice, 1976)

$D$-the thickness of the aquifer

The effective radius $R$ is also estimated by the following equation:

$$
\mathrm{R}=\frac{1.84+0.21 \ln \left[\Lambda \Lambda(\mathrm{L} / \mathrm{r})^{2}\right]}{1+1.61\left[\left(\frac{\mathrm{D}-\mathrm{L}}{\mathrm{D}}\right)^{1 / 2}\right](\mathrm{L} / \mathrm{r})^{-5 / 8}}
$$

Where, $\Lambda \Lambda$ is the constant that characterize the soil capillarity as a function of soil texture (Rupp et al., 2001).

According to Tahal-MCE, 2007, the thickness of the aquifer (D) in the area is approximated to be around30 meters. The soil texture is taken from the soil texture map of the study area (Fig 2B) and the values for " $\Lambda$ " (Schaap constants) are taken from (Table 13). Therefore, the values for clay, clay loam and silt clay soil textures of the study area are $47.3 \mathrm{~m}, 8.39 \mathrm{~m}$ and $17.7 \mathrm{~m}$ respectively. Finally, the computed values for hydraulic conductivity of the aquifers range from $1.63 \mathrm{~m} /$ day to $7.27 \mathrm{~m}$ /day with an average value of $4.9 \mathrm{~m} /$ day. 
Table 13. The values of " $\Lambda$ ” for soil textural classes (Schaap, 1999).

\begin{tabular}{|lllllllllllll|}
\hline $\begin{array}{l}\text { Soil } \\
\text { texture }\end{array}$ & Sand & $\begin{array}{l}\text { Loamy } \\
\text { sand }\end{array}$ & $\begin{array}{l}\text { Sandy } \\
\text { loam }\end{array}$ & Silt & $\begin{array}{l}\text { Clay } \\
\text { loam }\end{array}$ & Loam & $\begin{array}{l}\text { Silt } \\
\text { clay } \\
\text { loam }\end{array}$ & $\begin{array}{l}\text { Silt } \\
\text { loam }\end{array}$ & $\begin{array}{l}\text { Sandy } \\
\text { clay } \\
\text { loam }\end{array}$ & $\begin{array}{l}\text { Silt } \\
\text { clay }\end{array}$ & Clay & $\begin{array}{l}\text { Sandy } \\
\text { clay }\end{array}$ \\
\hline$\Lambda, \mathrm{m}$ & 0.43 & 1.17 & 4.06 & 7.15 & 8.39 & 8.58 & 9.20 & 9.58 & 12.36 & 17.7 & 47.3 & 55.24 \\
\hline
\end{tabular}

\subsection{Transmissivity (T)}

Transmissivity is defined as the rate at which water is transmitted through a unit width of an aquifer or confining bed under a unit hydraulic gradient. It is a function of properties of the liquid, the porous media, and the thickness of the porous media. Transmissivity is the product of the hydraulic conductivity and the saturated thickness of the aquifer:-

$$
T=b k
$$

Where,

$T$ - Transmissivity ( $\left.\mathrm{m}^{2} / \mathrm{d}\right) ; b$ - Thickness of the aquifer $(\mathrm{m}) ; k$-Hydraulic conductivity $(\mathrm{m} / \mathrm{d})$.

The Transmissivity values of the aquifers in the study area range from $48.9 \mathrm{~m}^{2} /$ day to $218.1 \mathrm{~m}^{2} /$ day with the average value of $147.14 \mathrm{~m}^{2} /$ day.

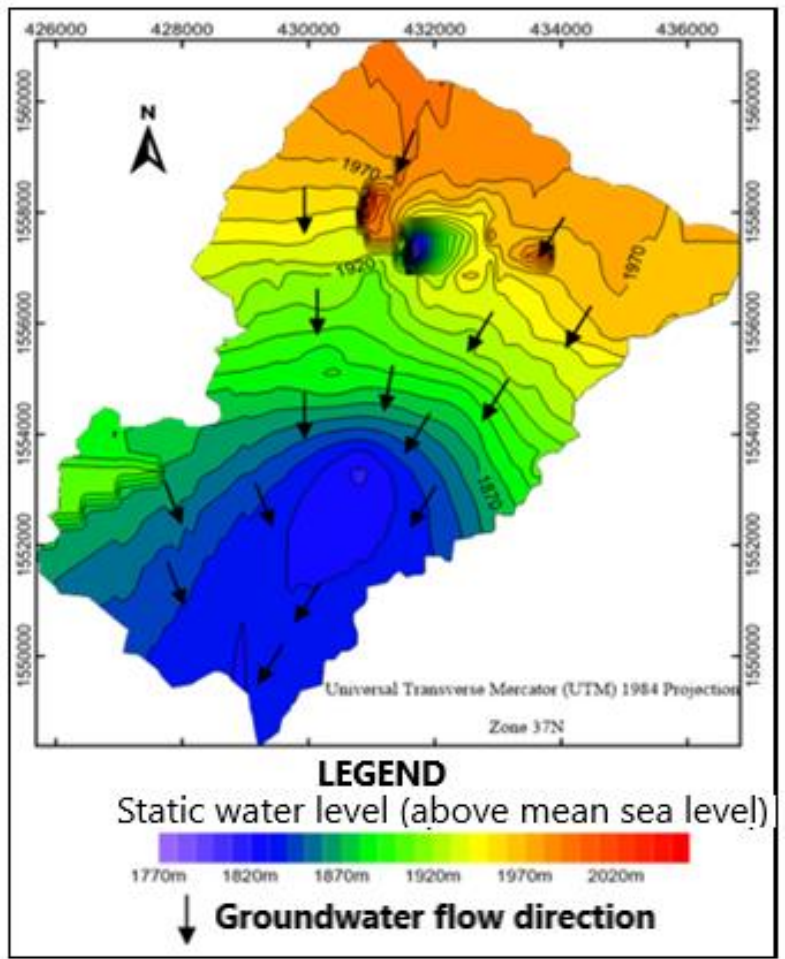

Figure 11.1 Groundwater flow direction in the study area.

\subsection{Groundwater Flow Direction}

In this research work, groundwater level contour map (Fig 11) is produced in the ArcGIS environment based on the static water level data collected from springs and shallow hand dug 
wells. The regional groundwater flow directions are then indicated perpendicular to the groundwater level contour lines by assuming the local variations in the hydraulic conductivity of the aquifers will not significantly affect the regional flow direction. Accordingly, the shallow groundwater in the area mainly flows in the south west directions similar to the surface water flow direction.

\subsection{Aquifer Productivity}

Productivity of the aquifers in the study area is categorized based on Zekai Sen (1995) classification (Table 14). Accordingly, the aquifers in the study area are categorized into the low to moderate potentiality.

Table 14. Standards of aquifer potentiality based on Transmissivity (Zekai Sen, 1995).

\begin{tabular}{|llllll|}
\hline Transmissivity $\left(\mathrm{m}^{2} / \boldsymbol{d}\right)$ & $<0.5$ & $\mathbf{0 . 5 - 5}$ & $\mathbf{5 - 5 0}$ & $\mathbf{5 0 - 5 0 0}$ & $>\mathbf{5 0 0}$ \\
\hline Aquifer potentiality & negligible & weak & low & moderate & high \\
\hline
\end{tabular}

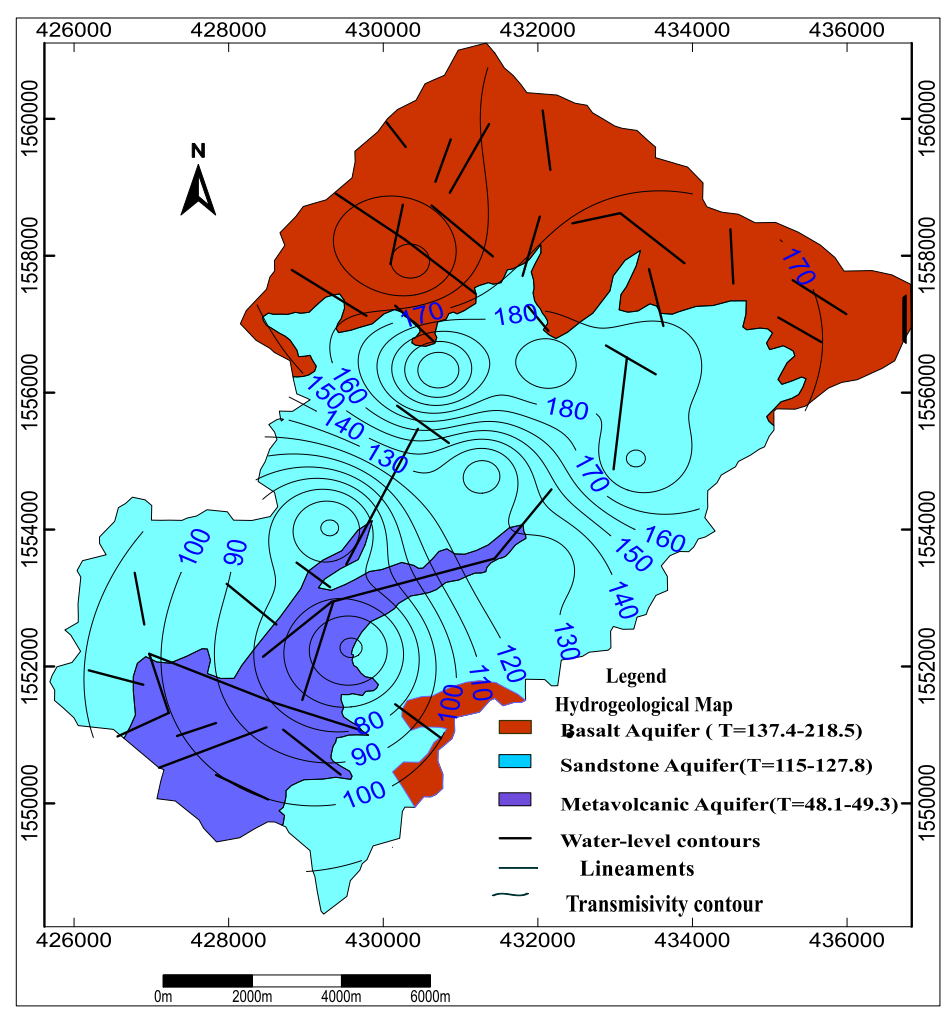

Figure 12. Aquifer productivity map of the study area.

The aquifers in the highly weathered basalt and highly weathered siltstone sandstone intercalation have Transmissivity values that range $99 \mathrm{~m}^{2} /$ day to $218.1 \mathrm{~m}^{2} /$ day (with the average value of $157 \mathrm{~m}^{2} /$ day) are grouped into the moderate potentiality aquifers 
category. Whereas, the aquifers in the slightly weathered and fractured metavolcanics, which have Transmissivity values that are less than $50 \mathrm{~m}^{2} /$ day (with the average value of 48.9 $\mathrm{m}^{2} /$ day), are grouped into the low potentiality range (Fig 12 ).

\section{CONCLUSIONS}

The geology of the study area from bottom to top is constituted by metavolcanics, mudstonesandstone intercalations and basalt rocks. Most irrigation dug wells are found in the sandstone-mudstone intercalation. The potential evapotranspiration, actual evapotranspiration and runoff are estimated for the water balance computation. The annual groundwater recharge is estimated to be $29 \mathrm{~mm} / \mathrm{year}$ and the total annual groundwater abstraction is estimated $25 \mathrm{~mm} /$ year. The annual net change in groundwater storage is $4 \mathrm{~mm}$, which should be zero for the hydrologic system under steady-state condition. This can be accounted for the groundwater outflow through deeper groundwater flow in the fractured mudstone - sandstone intercalation. The groundwater recharge rate is expected to remain constant while the total annual groundwater discharge is expected to increase from year to year. This relation when projected over a long period may result in negative groundwater budget which can result in depletion of the groundwater and deterioration of water quality. The ranges of hydraulic conductivity of the different aquifers in the area are computed and their potentiality categorized into high, moderate and low.

\section{ACKNOWLEDGEMENTS}

The authors are thankful to the Woreda Medebay Zana administration and Mekelle University for their all inclusive support during the research work. The water and agriculture bureaus in the region and at Woreda levels and other offices who provide secondary data are acknowleged. The authors are also greatful to the two anonymous reviewers and the editors for their constructive comments and suggestions.

\section{CONFLICT OF INTEREST}

There is no conflict of interest.

\section{REFERENCE}

Alemneh, D. 2003. Integrated natural resources management to enhance food security: The case for community-based approaches in Ethiopia. Food and Agriculture Organization of the United Nations, Rome, Italy. 
Beyth M. 1972. The geology of central and western Tigre. PhD Thesis, University of Bonn, Germany, $155 \mathrm{pp}$

BoPF, 2018. Annual report of the Tigray Bureau of Planning and Finance for the year 2017/18. Mekelle, Ethiopia.

Brassington, F.C. 1988. Field hydrogeology. John Wiley \& Sons, Chichester, 175p.

Crowe P. R. 1971. Concepts in climatology. London: Longman. 98pp.

Chow, V.T., Maidment, D.R \& Mays, L.W. 1988. Applied Hydrology. McGraw-Hill, New York, NY.

FAO. 1985. Water quality for agriculture. Food and Agricultural Organization (FAO) of the United Nations. FAO, Irrigation and Drainage Paper, No.29, Rome.

FAO. 1994. Sustainable Agriculture and Environment Rehabilitation in Tigray working documents.

Fetter, C.W. 2001. Applied Hydrogeology. Prentice Hall, Inc., New Jersey.

Fletcher, J. C., Burtis, K. C., Hogness, D. S \& Thummel, C. S. 1995. The Drosophila E74 gene is required for metamorphosis and plays a role in the polytene chromosome puffing response to ecdysone. Development, 121: 1455-1465

Freeze, R.A \& Cherry, J.A., 1979. Groundwater. Prentice Hall, Englewood Cliffs, 624p.

Hargreaves, G. H \& Samani, Z. A. 1982. Estimating Potential Evapotranspiration. Journal of Irrigation and Drainage Division, 108 (3): 225-230.

Jensen, M. E., Burman, R. D \& Allen, R. G. 1990. Evapotranspiration and irrigation water requirements. ASCE manuals and reports on engineering practice, No.70, ASCE, New York.

L'Vovich, M. I. 1979. World Water Resources and Their Future. American Geophysical Union, AGU, Washington, D. C., 415p (doi:10.1029/SP013).

Mace, R. E. 1999. Estimation of hydraulic conductivity in large-diameter hand-dug wells using slug test methods. Journal of Hydrology, 219: 34-45.

Makink, G. F. 1957. Testing the Penman formula by means of lysimeters. Journal of the Institution of Water Engineers, 11: 277-288.

MoARD 2008. National guidelines of daily water requirements for Livestock. Ministry of Agricultural and Rural Development. Addis Ababa, Ethiopia.

MoWR and Japan International cooperation 2001. Groundwater investigation, water well management and pumping test analysis. Addis Ababa, Ethiopia. 
National Meteorological Services Agency/NMA 2001. Initial National Communication of Ethiopia to the United Nations Framework Convention on Climate Change. Addis Ababa, Ethiopia.

Penman, H. L. 1948. Natural evaporation from open water, bare soil, and grass. Proceedings of Royal Society of London, A193:120-146.

Priestley, C. H. B \& Taylor, R. J. 1972. On the assessment of surface heat flux and evaporation using large scale parameters. Monthly Weather Review, 100: 81-92.

Rupp, D.E., Selker, S \& Jirka Simunek. 2001. A modification to the Bower and Rice method of slug-test analysis for large diameter hand-dug wells. Groundwater, 39: 308-314 (doi.org/10.1111/j.1745-6584.1989.tb00453.x).

Samia, Z. 2007. Population and housing census of Ethiopia: Statistical Report for Tigray Region. Mekelle.

Schapp, M. G., Leij, F. J \& van Genuchten, M.T. 1998. Neural network analysis for hierarchical prediction of soil water retention and saturated hydraulic conductivity. Soil Science Society of America Journal, 62 (4): 847-855

Shaw, E. M. 1988. Hydrology in Practice. Van Nostr and Reinhold, New Fetter Lane, London.

TAHAL- MCE report 2007. Groundwater development of Shire - Endaselassie. Mekelle.

TARI (Tigray Agricultural Research Institute). 2012. Soils map of Tigray. TARI, Mekelle, Ethiopia (unpubl.).

Thornthwaite, C. W. 1948. An approach towards a rational classification of climate, Geogr. Rev., 38: 55-94.

Thornthwaite, C. W \& Mather, J. R. 1957. Instructions and tables for computing potential evapotranspiration and the water balance. Publications in Climatology, Laboratory of Climatology, Drexel Institute of Technology, Centerton, New Jersey, USA, 10, 183311.

Turc, L. 1961. Water requirements assessment of irrigation, potential evapotranspiration: Simplified and updated climatic formula. Annales Agronomiques, 12: 13-49.

WHO 2011. Guidelines for drinking-water quality - 4th edition. Geneva, Switzerland.

Zekai Sen 1995. Applied Hydrogeology for Scientists and Engineers. $1^{\text {st }}$ edition, CRC Press, $464 \mathrm{p}$. 